\title{
Knowing the Father
}

\author{
Prof David T Williams \\ Adjunct Professor \\ University of Fort Hare \\ Alice Eastern Cape \\ South Africa \\ 0725911941 \\ dwilliams@ufh.ac.za \\ DOI: https://doi.org/10.46222/pharosjot.1021
}

\begin{abstract}
The emergence of the Charismatic movement has generated a new awareness and interest in the Person and work of the Holy Spirit, but has also brought a realisation that there is a still-neglected Person of the Trinity, the Father. Part of the reason for this lies in the historical development in the doctrine of the Trinity, which led to a belief that external actions of God are not differentiated between the Persons, and also in the fact that the Father only generally acts in the world by Son and Spirit, so has no clear role. It seems natural to attribute creation to the Father, but even here, the Bible sees the Son as the actual creator. Nevertheless, the Father can be seen as the source of the concepts and means behind the material; interestingly there are hints of this in classical Greek thought and other faiths. This is ongoing, perhaps particularly in the evolutionary process of the world. Thus, paralleling the incarnation, the Father is present in the material universe, as its ethos. He can also be seen to be affected by creation, sharing in its nature in his kenōsis, and in its suffering. Creation then inspires a sense of wonder not only from its existence, extent and nature, but from its interactions and underlying concepts; this is worship of the Father. Sin is then when this is overlooked, or when actions disrupt it; these are an offence to the Father.
\end{abstract}

Keywords: Trinity, appropriation, creation, wisdom, Fatherhood.

\section{Introduction}

There was a move a few decades ago in some groups to administer baptism in the name, not of the Trinity, but taking the few texts such as Acts 8:16 very literally, in the name of Jesus only. This is to neglect other texts, and also most of early church practice, which has even practised a threefold baptism (LaCugna 1993:131). However, the modern move has highlighted the fact that Christocentrism, in itself a great and necessary virtue, has sometimes eclipsed the Persons and works of Father and Spirit. With the Pentecostal revival, the work of the Spirit has regained recognition, but not that of the Father. Libraries contain but little specifically on the Father; interestingly one I visited contained but two works, but, interestingly, each was written by a person active in the Charismatic movement. Perhaps a reestablishment of Trinitarian balance is an indication of the truth of the Charismatic emphasis?

However, a problem lies in realising such a hope. Whereas the work of Christ in redemption is clear, and while, at least since the Pentecostal "revival", and the same pertains as regards the activity of the Spirit, albeit with doubt and discussion in several quarters, the work of the Father seems largely invisible. Yet when the bible does make descriptions of the activity of separate Persons, are they fictitious? Surely not. Can his works be seen as directly applicable to Christian faith, and especially on a day to day basis, as with the work of the other two Persons? Christian life and belief can only be enriched by appreciating these. How 
can a Christian relate specifically to the Father? Relating to this is the fact that the Bible does use the term "Father", which must surely be a metaphor; but why did God choose that one?

I want to suggest that there are two basic reasons for the neglect of the Father in Christian life and belief. On the one hand $\mathrm{He}$ is not prominent in the Bible, and on the other, the Fatherhood of God relates to another neglected aspect of belief, the Holy Trinity.

It must be added that a further significant reason is that due to movement in modern society, there is understandable reticence to speak of the Father; it seems to savour of unfashionable patriarchalism. Especially when it attributes creation to the Father; it was often felt that the mother was simply a garden to provide an environment for the seed of the father. This is one reason for the popularity of referring to such as "creator, redeemer and sustainer", although this is criticised (Cunningham 1998:73n41). Wainwright's belief is that this tends to Sabellianism (Thompson 1994:115). Most significantly, the picture can spoil the emphasis on personal relationship and so God's love. Moltmann (eg 1981:164) tries to keep this but avoid the stigma of the male image by speaking of the "motherly Father" (and fatherly Mother), noting some relevant biblical images and the decision of the 675AD Council of Toledo that the Son came de utero Patris. Perhaps more importantly is that reference to God as the Father is consistently biblical; perhaps sadly, Athanasius said that this is the only reason for the appellation (Thompson 1994:117).

\section{Biblical material}

It is hardly surprising that there is very little indication in the Old Testament of any action specific to the Father, with a mere five texts (Deuteronomy 32:6, Isaiah 63:16, 64:8, Malachi $1: 6,2: 10)$. These call God "Father", so recognising fatherly qualities in him, but there are no Trinitarian implications. More surprisingly, the situation is not really that different in the pages of the New. There are almost no references in the gospels to the action of the Father. Although Jesus constantly refers to him, there is almost nothing attributed to him. So although in the three synoptic gospels there are many references to the Father, there is almost nothing pertaining to specific activity in the world. What there is, is of two sorts. Firstly there are a few texts indicating the provision of the Father, such as his care for the birds (Matthew 6:26); "yet your heavenly Father feeds them". Here it does not need to be reference to specific action, but to the fact that the way that the world operates results in food for the birds. Secondly, while there are several indications of the Father's knowledge of what is happening, and of his response to this, such rewards can readily be understood as eschatological, so not in this time.

Apart from these, there is the revelation to Peter of the fact that Jesus is the Christ (Matthew $16: 17)$; this is naturally understood of revelation through the Spirit. Then there is the fact of prayer, such as the Lord's prayer (Matthew 6:9), or the hearing by the Father of those agreeing together (Matthew 18:19). In both cases, those who pray are specifically identified as disciples; Jesus specifically indicated, in his prayer to the Father (Matthew 11:27), that nobody could know the Father except through the Son. It might just be noted here that the text significant to the "prosperity gospel" (Mark 11:24) does not specifically mention the Father at all. It is hardly surprising that none of my basic theology texts even lists the category of "father"!

It was only with Jesus, as the Son of God, that the Fatherhood of God became prominent. With this focus in John's gospel, there are more references, but almost all are of Jesus' relation to God. The Father works, but through the Son and the sending of the Spirit, very prominent in John 14-16. The Father has given all into the hands of the Son (John 3:35); Jesus emphasises that seeing him is seeing the Father (John 14:9). When referring to John 
17, Hilary of Poitiers stressed that Jesus sought to make God known specifically as Father; "the revelation is not of the Father manifested as God, but of God manifested as the Father" (Torrance 1996:139); perhaps this was wrong. It is then quite striking that in response to the coming of Greeks to Jesus, there did come the voice of the Father from heaven (John 12:28); unless it was as some bystanders said, actually the voice of an angel.

Then if Jesus had such a vital appreciation of the Father, that should mean that Christians, as adopted children, should have one as well. But this is not the case.

\section{Neglecting the Trinity}

Indeed, Christian faith should be a vital relationship with all three Persons, and in fact be thoroughly Trinitarian; but is it? The doctrine of the Trinity should be central! The focus and the heart of faith should be on the nature of the Godhead. If it is not, all other aspects of faith are out of focus. Cunningham (1998:19) and Thompson (1994:v) in fact note a recent revival of writing on the Trinity. However, it is a feature of modern church life that the Trinity is largely unknown; the reasons for this are not hard to find. But are they really Christian?

The Christian faith is founded upon an amazing affirmation, that the man Jesus, born in Bethlehem of Judea, and brought up in the family home of Nazareth in Galilee, was, or should we rather say "is", God himself, deity incarnate. Such an affirmation is so stupendous as to be hardly believable, yet within a century after his birth came the staggering assertion that unless a person accepted this, he or she could not be Christian, and then could not be saved. Indeed, it may justly be said that the very fact that millions of people have accepted that affirmation, stupendous as it is, is strong evidence that it is in fact true. One of the greatest minds of the first few centuries, the lawyer Tertullian, said in a manner very typical of him, "I believe because it is absurd".

However, with such a belief, there came an immediate problem. With very few exceptions, the early Church, and indeed Jesus himself, while categorically affirming the full deity of Jesus, affirmed the existence of two other divine persons, Father and Holy Spirit, at the same time. If that was not enough, the Old Testament, which the Church naturally accepted, emphatically stressed the absolute oneness of God.

The infant Church was much too concerned with mere survival for its first three centuries to try to understand how these affirmations fitted together, but once the Christian faith had been accepted by the Roman empire, and there was the possibility of giving more attention to understanding it, for quite a long time, the focus of attention was in fact, on the Trinity. This is strange to our ears, but of course the realisation of the incarnation had to revolutionise the idea of what God is like. There was a succession of controversies and the associated councils before there was general acceptance of the shape of the doctrine which has come down to the modern age. The basic issue had been the ideas of Arius, who had believed the Son to be a lesser deity than the Father; a long battle resulted in an affirmation of absolute equality of the Persons. Thereafter, there was little interest or writing on the subject apart from a very few notable works such as by Augustine, but these did not really constitute any serious advance. LaCugna (1993) details the development in doctrine, culminating in the work of Aquinas (1993:143f); essentially, however, the need to maintain belief in equality of the Persons after the Arian controversy had finally led to the belief that Trinitarian distinction was not manifested outside of God. As Augustine had said, the belief was that opera Trinitatis ad extra indivisa sunt.

With this background, and of course the difficulty of the doctrine, it is perhaps not surprising that some modern writers have noted that the doctrine of the Trinity has been neglected for a very long time (Cunningham 1998:12); and really, despite a bit of a resurgence in recent 
decades, the situation continues the same. The interest, where it has existed, remains on the understanding of inner-Trinitarian relationships. Especially in western theology, the essential meaning of the Fatherhood of God is Father of the Son (LaCugna 1993:155, Moltmann 1981:163). Surely he is more than that? Debate has been between those who put more stress on Threeness, as in the "social Trinity", or on Oneness, mere modalism. In the modern world, such limitation of interest is fatal. In the modern pragmatic age, interest, and so devotion, can only be maintained if there is relevance; this means that there must be a clear distinction between the Persons on the basis of what they do. The Fatherhood of God must affect the world, and indeed individual believers. Without this, the doctrine remains irrelevant to life, and so is neglected, effectively forgotten (LaCugna 1993:144). This means that the Father is also effectively forgotten; but this can hardly be right.

Yet a look at even the modern writings on the Trinity reveals that this question is just not being answered. Bray (1993:124) complains that in effect, most Christians are Unitarian! Rahner (1970:10) comments that if the doctrine of the Trinity were dropped as false, the major part of religious literature could remain unchanged (cf also LaCugna 1993:213). It is not hard to suggest why. For one thing the doctrine is admittedly difficult, and there is an understandable fear of falling into one of the early heresies. While there is really little doubt that it is essential if the key beliefs of the faith, such as the full deity of Christ and the unity of God are to be maintained, the Fatherhood of God remains a second level doctrine, only held because of others.

\section{Appropriations}

The Augustinian ad extra means that there is no distinction between the actions of the Persons in the world; they are only distinguished in God's immanence, so never observed. Yet in an inevitable reaction, it was posited that actions could be "appropriated" to specific Persons; these were those felt to be "appropriate". LaCugna (1993:102) says that once the Augustinian ad extra is affirmed then there is a need of the corrective of appropriation. In practice creation was appropriated to the Father, redemption to the Son, and divinization to the Spirit.

Emphatically, according to Augustine's theology, the ad extra is maintained; it is the Trinity that creates, redeems, divinizes, but just appropriated to the distinct Persons. The doctrine of appropriations became prominent in the theology of Augustine, Aquinas and Palamas (LaCugna 1993:212). Thus Aquinas says that the divine essence creates, but the action is appropriated to the Father (LaCugna 1993:159).

Much later, Calvin did query the idea of appropriations (Bray 1993:202), feeling it is effectively Sabellian. Rather, he believed that all works are done by all Persons. Calvin however did feel that aspects in specific works could be separated. Notably, he saw Christological mediation of divine action in creation, and that of the Spirit (Gunton 1998:152).

The doctrine of appropriation is not a real identification of role, as all are actions of God, but brought in to help comprehension (Cunningham 1998:117, LaCugna 1993:98). "all the works of God are the work of all Three, acting in concert; nevertheless, by appropriating a particular work to one of the Three, we may be able to understand it more firmly and to articulate it more persuasively" (Cunningham 1998:118). However, in practice, an idea which was supposed to clarify understanding, has in fact done the opposite; it has impoverished it. Likewise, as Milne (1997:299) says, the idea of redemption is impoverished by a lack of Trinitarian perspective. Rather we should seek to understand more fully and exactly.

It might also just be observed that while Augustine's major work on the Trinity, de Trinitate, emphasised the equality of the Persons, the work used analogies or vestigia. For 
Bonaventure, relation between Father and Son is the ontological basis of all other relations; hence created reality bears the stamp of Sonship (LaCugna 1993:179 n219). Thus, creation is logical as the Son is logos, moral as Son is moral, expressed as Son is expressed. What does this say of the Father?

A reaction to the longstanding view came especially from the work of Karl Rahner, who suggested that "the economic Trinity is the immanent Trinity, and vice versa" (Rahner 1970:22, also 63). Distinction between the Persons in the inner being (immanence) of the Trinity should reflect in its manifestation (economic) in the world, if it is a real selfcommunication (LaCugna 1993:214). Rahner resisted the development in Trinitarian theology that had deduced from the absolute equality of the Persons that there could be no distinction in the "economy". It cannot be right to deny distinctive actions in the world. Rahner (1970:23) particularly pointed out that the action of the second Person is unique; only he became incarnate. He stresses that the doctrine of incarnation connects God's being in economy and God's being as such (LaCugna 1993:212). Likewise, for example, it is not correct to say that the Holy Spirit reconciled the world (LaCugna 1993:100). The Biblical witness had been overridden for dogmatic reasons. Scholastic theology had severed the theology of God and the theology of God for us (LaCugna 1993:216).

What can and should be affirmed is that every Person is involved in the work of the others. A work is really appropriated to a particular Person, but not to deny the concerted contribution of the others. This is an aspect of perichōrēsis. "we can speak of one Person as eminently involved in a given operation, all three Persons are involved in the operation of each" (Turner 1969:242). "each is intimately involved in the mission of the other (the Spirit announces and confirms and sustains the incarnation, and the incarnate Word "breathes out" the Spirit on the disciples)" (Cunningham 1998:219). Incidentally this indicates why Jesus was only active after he had received the Spirit.

Every Person is involved in every outward act of God. "thus Father, Son, and Spirit are all involved in the work of creation, which is not to be viewed as the work of the Father alone" (Milne 1997:299). "Yet it is appropriate to think of creation as the work of the Father ... it is properly seen as the distinctive action of the Father" (Milne 1997:299). "of course, since the divine essence is three persons, the power of creating proper to the divine essence must belong to the three persons each in its own way" (LaCugna 1993:159). Ironically, while traditional theology ascribes the actions of the undifferentiated deity, it often says it is by the Father (Rahner 1970:60); probably some or all should be attributed to one of the other two Persons.

Such harmony is not identity; all are involved, but in distinct ways (Cunningham 1998:115). Cunningham (1998:78) points out that as God is simultaneously agent, action and act, this requires divine self-differentiation. Perhaps this is implied in the prepositions in Romans 11:36. The action of perichōrēsis enables the three Persons to be distinct and different, but in complete interaction and harmony; there is one God. In this case, the Father does have a unique role, the other Persons do not act in that way, but are in harmony with it.

It is hard to escape the conclusion that distinction between the Persons in the world must be real, even if at the same time it is affirmed that the work of each does depend on the others. Grudem (1994:248-9) affirms that the Persons have different functions in relating to the world. The question is then of the distinctive role of the Father.

\section{Action of the Father}

Nevertheless, a quick look at the Bible reveals very little ascribed particularly to the Father. Is there a distinctive role for him? One suggestion was that of Barth, who describes the 
essential nature of God as Revealer, Revelation and "Revealedness" (McGrath 1997:307). Bray (1993:191) helpfully (?) gives the Latin as revelans, revelatum and revelatio. This would be a direct action of the Father into the world. However, there must be a hesitation, as the Biblical witness rather describes the Son as the revealer; "he who has seen me has seen the Father" (John 14:9). Except for the baptism of Jesus, revelation is by the Son, and even there, the Father rather acclaims. In fact it could well be more accurate to suggest that at the baptism, Jesus was rather revealing the Father, the Father of the Son.

The obvious work of the Father seems that of creation, the action that traditional theology has appropriated to him (Rahner 1970:58), as in the traditional description of the work of the Trinity as "creator, redeemer and sanctifier". In addition to the Biblical witness, it is natural to see the first Person as Father because of human fatherhood. After all, does not Ephesians 3:14 connect them? Indeed, humanity does image God, so a human father should image the Father.

Nevertheless, this is questionable. LaCugna (1993:214) particularly points out that in the theology of Augustine and Aquinas there is no real connection between the Trinity and creation; for them, it is an external work, so it is God who creates. On the whole, the Trinity was viewed as irrelevant to the means of creation (Gunton 1998:154). Moltmann (1981:164) emphasises, "God is Father solely in respect of the only Begotten Son. No fatherliness in the literal sense can be detected from the creation of the universe, or from providence." Indeed, although it can only be divine, it is not a function of fatherhood to originate; that would be pagan. Thus, apart from a very few, "today's theology hardly ever sees any connection between the Trinity and the doctrine of creation" (Rahner 1970:13).

Then although the fact of creation is prominent in the Old Testament, and although the link between creation and fatherhood is an obvious one, the fact that there are only a couple of references there to the Fatherhood of God indicates that it is unlikely that creation in the Old Testament is seen in terms of fatherhood. In any case, as the prime Biblical understanding of God's Fatherhood is of Jesus, that would not normally be in the Old Testament.

That Fatherhood should not be primarily linked to creation is also seen in that, as Jeremias observes, there are no instances of prayer to Abba in Judaism (Smail 1980:39). Rather, the rare use of "Father" in the Old Testament is linked specifically to Israel as the covenant people; he has enabled the possibility of relation. God then is not father by virtue of existence, but becomes father. He has taken a people, and acted on them as a potter on the clay (Isaiah 64:8), in redemption. The situation is similar, and clearer, for Christians, God becomes Father, due to the bestowal of new life in regeneration; only Christians can legitimately pray the "Our Father", the Lord's Prayer (Smail 1980:38). Indeed, the idea of God's universal fatherhood is pagan (Smail 1980:34).

Fundamentally, although one can affirm that as Father, he created, it is not right to say that he is Father because he created. In any case, the natural link between fatherhood and creation would tend to imply that God became Father, for there was a time before the world was made. But God, as God, is eternal. Indeed, a catchphrase of the Arians, seeking to deny the full deity of the Son, and appealing to such as Proverbs 8:22 and Colossians 1:15, was that "there was when he was not." They identified wisdom with the logos, or "word" of God, and so the pre-incarnate second Person, and then took these texts to mean that the Son was not eternal, so fully divine, but a created being. However, even if this identification is correct, the key-word "first-born" can mean not the first in creation, but as generated (Carson 1960:42); perhaps also in a causal sense, so referring to Christ as the actual creator. However, the figure of wisdom is not here a hypostasis, but a metaphorical personification. Kidner (1964:78) points out that the next chapter uses a different personification. Significantly, Proverbs 8:22 uses the word qanah, better rendered 
"possessed" rather than "created" (Grudem 1994:230). Kidner (1964:79) observes that the verb qana" rarely bears the connotation of "create", but rather "get" or "possess". Indeed, wisdom is indeed the first action of God in the creation process; it is the essential activity prior to actual creation.

\section{The Father as foundation}

The Biblical witness is that "all things were made through him" (John 1:3), but where the previous verse indicates that this is by the Son, distinct from, but with, God. Indeed, creation would seem to have been not the work of the Father alone, but was through the Son, especially as the "Word" of God. While 1 Corinthians 8:6 indicates that all is FROM the Father, it immediately says that it is THROUGH the Son. The same is indicated by Hebrews $1: 2,2$ Pet 3:5, and Colossians 1:16. One other indication is Hebrews 1:10, where "the heavens are the work of your hands". The same idea of the actual creation by the Word and Spirit is found in Psalm 33:6:"By the word of the LORD the heavens were made, and all their host by the breath of his mouth".

Gunton $(1998: 157,8)$ sees it reaffirmed in Barth and Pannenberg. Basically the first Person acts in general only through the other Persons, his "two hands", as Irenaeus said (Adv Haer 4.20.1, Gunton 1998:54, cf Williams 2003). It is then also the work of the second Person not only to actually create, but to maintain what has been made (Hebrews $1: 3$ ). This of course touches what has been a long appreciated problem, what happened to the universe at the death of Jesus.

However, the act of creation has a prerequisite. While creation is naturally seen as by the "Word", a word is fundamentally a production from thought, or wisdom, even if it is not actually uttered. Indeed, wisdom is an organisational term, indicating the way in which things relate together. Martin Buber writes "in the beginning was relation" (Moltmann 1993:11). The utterance of words depends on the organisation of wisdom; this is prior, in human activity, both from a logical and temporal perspective. In this case, wisdom rather refers to the characteristic of the Father. The Father is seen as giving the plan (Ephesians 1:3f especially v10 also 1 Thessalonians 3:11). He directs and the Son acts. Creation then indeed comes from the Son as the expression of wisdom in the Word, but also through the Spirit. In human fatherhood, the function of a father is really not so much to produce the child; that is the role of the mother, who provides for, feeds, and gives a supportive environment. Rather, what a father does, albeit with the mother, is to give the DNA, so the essential pattern for the new being of the child. The essential role of fathering is not making, but ordering. The father gives (part of) the form, but the mother does the making; so procreation is paralleled by the creation process (cf 1 Corinthians 8:6). This is not Moltmann's "motherly Father"! Then the mother suffers in the birth process as Jesus suffered to bring forth new creation.

Indeed, there must be action prior to an actual making. When an object, such as a car, is made, the first action is the design and understanding of what it would be like. It is only when that is done that the actual production is commenced. If the illustration is read back to God's creation, the initial stage is to give the conceptual basis to what is then actually made. This can be readily seen to be the work of the Father, in wisdom, then enacted by the agency of the Son. To just complete the illustration, the car is then given life, and the Spirit enlivens the creation that was made. Obviously, of course, although the three are distinguished, they are totally interrelated. The concept of the car depends on the possibilities than can be made, and the specific fuel, likewise the other two actions depend in turn on the others.

Another illustration is from music (cf Cunningham 1998:127f), where the initial work is conceptual, including the writing down. It is usually produced by other people, on their instruments. There is then a means of bringing it to us. A Trinitarian pattern seems, to me, to be present! 
Indeed, Basil the Great wrote of "the Father as the preceding cause, the Son as the One who createth and the Spirit as the perfecter" (On the Holy Spirit ch 38 (PG 32 136B), cited in Moltmann 1993:9). (Incidentally I would rather refer to the Spirit as the "enlivener"; this is more than bringing to a goal (Moltmann 1993:9).) A significant aspect of this is that as the Father gives the plan, this gives stress on eschatological fulfilment (1 Corinthians 15:24). This does not then imply that the Son is less, but that he delivers as the plan is completed.

So even if the Father does not actually create, he is involved as the origin of the concept and underlying principles. This is like saying that St Paul's cathedral was built by Sir Christopher Wren; it is true, but I doubt that he got his hands dirty. So the Father is responsible for the way that the world is and functions; in particular, it reflects him as it very often operates by means of agency. This is certainly true for human society, where we are dependent for so much of what we need on the work and the expertise of others. Interestingly, in his discussion of the creation account of Genesis 1, Blocher (1984:68) cites Jéquier's reference to Egyptian parallels in "very ancient cosmogonic texts", whereby "Hor represents the thought that conceives, Thot the word which executes"'. Gunton (1998:28f) also notes the theory of Plato's "forms", and that the same basic idea is in Augustine's view of the rationes seminales, forms of things whose creation precedes that of the material world (Gunton 1998:33). Without seeing direct dependence on Plato or the Stoics, the essential idea here may well reflect reality. Gunton (1998) elaborates his view later, as well as the similar views of such as Origen and Basil, also its virtual disappearance by the time of Aquinas (although not entirely (Gunton 1998:101, 117). It is even seen much later in Kant (Gunton 1998:131). Protestant scholasticism also sometimes adopted the Platonic idea of forms existing prior to actual creation in the mind of God (Gunton 1998:155). I would then suggest that the roles of the three Persons are more adequately described in terms such as "foundation, agent and empowerment". Incidentally, Moltmann reverses this, seeing the Father as the originator, the Son as giving shape and form (McGrath 1997:273).

The Father lives in the logical foundation of the universe; this has been described as panentheism. Confronting the philosophers in Athens, Paul quotes from the poet Epimenides, "in him we live and move and have our being" (Acts 17:28), arguing that he is not far from us, because he is the fount of our existence. That he is speaking of the Father is clear as he then refers also to the Son (Acts 17:31). Then, of course, at the same time, the Spirit can also be said to be incarnate, living in the interaction of life. Indeed, consistent with the view of the Son's action in incarnation, is the "incarnation" of the Father!

Essentially, there is no direct action on the world by the Father; all is actually that of the Son. To give one example, the appearance to Moses of God at the burning bush (Exodus 3) was, just as the theophany to Paul on the Damascus road, that of the second Person and not the first. After all, both are call narratives. The implication of this was that the name revealed to Moses was not that of the Father, but of the Son. Indeed, Paul's favourite title for Christ was "Lord", which goes back to that point (Exodus 6:3). The name revealed to Moses was of course "I am that I am", which is then claimed by Jesus on a number of occasions (eg Jn 8:58), recognised as a claim to divinity (eg John 18:6). There is then a distinction to be made between the titles given to the first two Persons, where in general the first is referred to as "God", the second as "Lord" (eg Romans 1:7). Perhaps a distinction can be made between the first which is rather an ontological term, and the second which is relational.

The only exceptions to this would seem to be at the baptism of Jesus (Luke 3:22), at the Transfiguration (Luke 9:35), and at the time of the visit by some Greeks (John 12:28), where there was a voice from heaven. Significantly, the message of the voice was the same on all three occasions, identifying Jesus as the Son. This is of course consistent with the function of the Father in the creation, designating identity and relationships. 
One aspect of fatherhood is that he disciplines his children (Hebrews 12:5f); it is part of their upbringing. This is particularly appropriate in respect of the first Person giving the system in which the universe exists and interrelates. The design of the Father includes moral foundation. This implies that there is discipline on departure from the system or way of life established by the Father. As such the Father is the fount of the Law, even if it was in fact given by the second Person. This is because it is the second who interacts with the world; thus Jesus said that the Father judges no-one but has given judgement to the Son (John 6:22), as it is the Son who commands obedience.

Incidentally, the suggestion of the Father as foundation impinges on the relationship of creation to the idea of evolution. It may just be noted here that a clearer distinction between the conceptualising of the creation and the actual making is perhaps more compatible with the view of "intelligent design", which I would prefer to term "theistic evolution". This is that the world was not created in a final state, but there is intervention from time to time; otherwise the processes of evolution, laid out by the Father, continue and proceed. This could be hinted at in John 5:17, where Jesus speaks of the ongoing work of the Father; the plan continues, it is then not just an act in the past. Indeed, it would seem unlikely that while the creative work of the second and third Persons is ongoing, that of the Son in upholding the creation (Hebrews 1:3), and of the Spirit in giving life, that of the Father was completed before the beginning. Rather, especially in keeping with the nature of the "living" God, the structure of things develops over time. Of course, the major change was with the incarnation and the means of salvation; with the return of the Son, the parousia, a further major change will occur. Probably the fact that this is not predetermined but is part of the ongoing work of the Father, reacting to the world, is the explanation for the fact that the date of the parousia was not known to the Son.

It is indeed not surprising that one thing that was identified by Jesus as specifically a function of the Father was the setting of the timeframe for the future (Acts 1:7). Here Jesus specifically denied knowledge of this (Matthew 24:36), ascribing it only to the Father. It has been suggested that this is part of the kenōsis of the second Person in which he limited his deity, and specifically his omniscience in his incarnation. This can well be so, but it is notable that he did seem on other occasions to be privy to knowledge not available to normal people, such as his knowledge of Nathanael (John 1:48).

\section{Kenōsis of the Father}

In order for existence to be possible, it was necessary for God to limit himself to enable the existence of an entity outside of himself, and in order to give it a measure of freedom. "Every action has an equal and opposite reaction" is a fundamental maxim. But a similar thing is always true; an act of doing affects the doer. This is true for God as well; God changes! The well-known passage in Philippians 2, in particular, highlights the self-limitation of the Son, and Moltmann (1993:102) then speaks of the kenōsis of the Spirit. In the perichōrēsis of the Persons, this is also experienced by the Father. However, it may be suggested that there is also an aspect of kenōsis particular to the Father, which would then of course be shared with the other Persons. Whereas he could lay down the pattern of the world in a total and complete way, he has limited this, which allows a measure of indeterminacy. Moltmann (1993:80) points out that the very act of creation is a further limitation, as God chose just one of the possibilities. In any case, he limited his absolute divinity insofar as there is a Son and Spirit (Cunningham 1998:295).

These experiences of self-limitation naturally relate to the nature and activities of the Persons, and then result in suffering particular to each Person. Moltmann (1993:69), as many others, reacts to the traditional view of the impassibility of God, tracing it to the 
incarnation. This relates to the Son, and it might be added that the reason for his suffering is not just entry into a world of suffering, sharing in it, but because suffering is a result ultimately of sin, he suffers because of that sin. The Father, however, also suffers, but not directly from the incarnation. Rather, as the giver of order and interaction, he suffers when these are compromised.

\section{The love of the Father}

Particularly as the natural belief that it was the Father who created seems a misconception, it must be asked why God revealed as Father and Son. It must surely be a metaphor, at least to some extent. Why is it the figure that Jesus used to explain the nature of God?

The key point of fatherhood, seen in God, is of giving. Indeed the heart of the act of fathering is just that; not again, to stress the point, creating. God, as Father, gave the gift of his Son. It is his fundamental act, and therefore reflects his very nature of love, which is inherently selfgiving. This was of course not a single act only, but one act of his nature. What follows is that the Christian life is also fundamentally of loving, of self-giving; in this the Father is imaged. Essentially, the underlying reason and motive for the incarnation, so manifest in the Son, is God's love. Again, of course, this is actualised in what the Son did. That well-known, and well-loved, verse reads "God so loved the world that he sent his only Son" (John 3:16, where, incidentally, older versions add the word "begotten"). Here, as Frost (1978:53) points out, as with several references to "God" in the bible, this should be understood in terms of the Father.

Particularly as regards the Father, underlying love is indeed also reflected in the act of creation; LaCugna (1993:265) observes that from an Eastern Orthodox perspective, Zizioulas believes that love creates new being. In contrast with the West, which sees creation as an act of will, the East sees it as an act of nature; as in many cases, probably both are valid aspects of the full picture. In this case, as God is love (1 John 4:16), it is the nature of God to create (LaCugna 1993:355). This is reflected in humanity, where it is the love of parents that produces new life. The incarnation, and the love behind it, manifest the characteristic of the Father seen in creation. Essentially, the Father originated the concept of the creation, which means the network of interactions of each element. This must be a perfect system, and what is love except a full interaction? Then the love in the incarnation is due to God's longing for the full relationship with humanity, which needed salvation. What the Father does is fundamentally produce love; it is natural to see the Father as love, especially as the elements of creation interact not only with each other, but with God.

\section{And so?}

The charismatic movement has alerted Christians to the need and benefits of a positive relationship with the third Person of the Trinity. As He is the source and means of life, relating to him in conformity to that life means that our human and spiritual lives interact. As a Christian is "in Christ", so he or she can be "in the Spirit". This suggests that the same is possible with the Father. Theology must lead to practice, or it is sterile and futile (Cunningham 1998:45).

Relating to the third Person has enhanced Christian experience for millions. However, if it is indeed valid to see the three Persons acting in different ways in the world, it must not be expected that relating to the Father is the same. In any case, the Father does not generally act directly in the world. The Father is in the world, but in his wisdom; it is through this that we relate. 
Practically this means conformity with the plan and purpose of God. This naturally will have several facets. Worship of the Father is an appreciation of the wonder of the creation; this is so common Biblically. It is not only the existence of things that excites our wonder and worship, but the way in which they work; this is worship of the Father! Perhaps the most topical is conformity with the way in which the world and universe operates; going against the interactions of the world as laid out by the Father is sin. The situation of global warming is due to this; human activity is out of line with the interactional system laid down by the Father, so the results are serious.

Also practically, even if the portrayal of God as Father must be metaphorical, it is there to give a pattern for human fatherhood, specifically in relation to children (Cunningham 1998:294). This in itself is an adequate reason for God's adoption of this metaphor.

Then seeing the work of creation divided into aspects highlights the fact that our actions follow the same pattern. In particular, before a specific action is done, there is a conception of it. These conceptions originate in the mind; thus Ephesians 1:17f speaks of the action of the Father giving "a spirit of wisdom and of revelation in the knowledge of him, having the eyes of your hearts enlightened, that you might know ...." The Father then gives ultimate meaning to Christian life, so spiritually as well as biologically. Hence it is the mind that needs renewal in Christian growth (1 John 5:20).

Conversion originates in repentance, metanoia, a change in mind. This is was the first command of Jesus' preaching (Mark 1:15); renewal of mind is indeed highlighted in Romans 12:2, Ephesians 4:23 and elsewhere. 1 Peter 1:14f then sees the implication of enlightenment to living a holy life. Notably, the same idea is reflected in Psalm 51:10, "create in me a clean heart", where the same word, bara', is used as in the creation narrative of Genesis 1.

\section{References}

Blocher, H. (1984). In the beginning: the opening chapters of Genesis. Downers Grove, III: Inter-Varsity.

Bray, G. (1993). The doctrine of God. Leicester: Inter-Varsity.

Carson, H.M. (1960). The epistles of Paul to the Colossians and Philemon. London: Tyndale.

Cunningham, D.S. (1998). These three are one: the practice of Trinitarian theology. Oxford: Blackwell.

Frost, R. (1978). Our heavenly Father. Plainfield, NJ: Logos.

Gunton, C.E. (1998). The Triune creator: a historical and systematic study. Grand Rapids / Cambridge: Eerdmans.

Kidner, D. (1964). The proverbs: an introduction and commentary. London: Inter-Varsity.

McGrath, A.E. (1997). Christian theology: an introduction. Oxford: Blackwell.

Moltmann, J. (1981). The Trinity and the kingdom of God: the doctrine of God. London: SCM.

Moltmann, J. (1993). God in creation: a new theology of creation and the Spirit of God. Minneapolis: Fortress. 
Rahner, K. (1970). The Trinity. London: Burns \& Oates.

Smail, T.A. (1980). The forgotten Father. London: Hodder \& Stoughton.

Thompson, J. (1994). Modern Trinitarian perspectives. New York: Oxford university press.

Torrance, T.F. (1996). The Christian doctrine of God, one Being three Persons. Edinburgh: T \& T Clark.

Turner, H.E.W. (1969). Opera ad Extra. In Richardson, A (ed) A dictionary of Christian theology. London: SCM. 242. 